\title{
AUTOELOGIO E IMAGEM DE SI EM NIETZSCHE
}

\author{
Self-Praise and Self-Image in Nietzsche
}

Fabrício Tavares Santos Silva ${ }^{1}$

Resumo: Pensamos aqui o autoelogio em Nietzsche como resgate de um gesto filosóficoético-estético antigo; algo como uma retomada de valores estéticos para reelaborar modos de existência que busquem superar determinados valores do cristianismo e da modernidade filosófica. Nesse sentido, perguntamos como as distorções do pensamento de Nietzsche lhe foram oportunas para que pudesse construir certas imagens intempestivas sobre si mesmo; e, também, como a retórica autoelogiosa de Nietzsche serviu para que pudesse afirmar seu pensamento diante de maus leitores, ou até mesmo de falsificadores, lançando assim sua filosofia como um dardo para o futuro.

Palavras-chave: Nietzsche, Autoelogio, Imagem de si.

Abstract: We think here about self-praise in Nietzsche as a rescue of an ancient philosophical-ethical-aesthetic gesture; something like a resumption of aesthetic values to re-elaborate ways of existence that seek to overcome certain values of Christianity and philosophical modernity. In this sense, we ask how the distortions of Nietzsche's thought were opportune for him to be able to build certain untimely images about himself; and, also, how Nietzsche's self-praising rhetoric served to enable him to affirm his thinking in front of bad readers, or even falsifiers, thus launching his philosophy as a dart for the future.

Keywords: Nietzsche, Self-Praise, Self-Image

"Bom é todo estilo que realmente comunica um estado interior, que não se equivoca nos signos, no tempo dos signos, nos gestos - todas as leis do período são arte dos gestos" (Ecce homo, Nietzsche)

Sabemos que Nietzsche reivindicou para si leitores de um tipo especial. Sabemos também que rechaçou aquela espécie comum - “os que leem por passatempo", dirá um

\footnotetext{
1 Graduado em Filosofia, especialista em Filosofia Moral e Política e mestre em Educação pela Universidade Federal de Pelotas (UFPel). Doutorando em Filosofia (Bolsista CAPES I) pela Pontifícia Universidade Católica de São Paulo (PUC-SP) com pesquisa sobre o papel da escrita no pensamento de Michel Foucault. E-mail: fabriciosantossilva@gmail.com
} 
fragmento de seu Zaratustra -, reafirmando ao longo de sua trajetória a necessidade de encontrar leitores que estivessem à altura de seu pensamento.

Essa não fora, porém, uma tarefa simples em sua época, especialmente entre seus contemporâneos alemães. A desconfiança com que era lido em sua terra natal o levava por vezes a adotar um tom violento na escrita, como é o caso de Ecce homo, sua autobiografia intelectual. Irônico, capaz de vangloriar-se pelo autoelogio de sua obra, frequentemente utilizando-se de referências diretas e indiretas à Antiguidade grega e romana, ou de autocitações de seus livros precedentes, em muitas passagens, parece, à primeira vista, não se importar com a opinião de seus críticos contemporâneos, em sua maioria composta pelos círculos wagnerianos e antissemitas da Alemanha do final do século XIX.

Precisamente em relação a esse ponto é que se torna importante uma contextualização histórica de sua produção. Isso na medida em que Nietzsche não só responde através da escrita aos ataques sistemáticos que seus livros sofriam por parte de seus contemporâneos, como também critica, em diversas passagens de seus livros, o nacionalismo e o antissemitismo que se disseminavam na Alemanha da época. Quer encontrar leitores com ouvidos finos, capazes de escuta apurada a seu pensamento. Mas para isso necessita combater e, sobretudo, diferenciar-se.

\section{CONTEXTO}

A despeito de interpretações psicológicas do pensamento de Nietzsche, o contexto de produção de Ecce homo ${ }^{2}$ parece revelar os embates do autor com seus contemporâneos alemães, não apenas em relação ao período que se aproxima da escrita dessa obra, mas também em relação a alguns aspectos do contexto de produção do pensamento de Nietzsche na década de 1880.

\footnotetext{
${ }^{2}$ NIETZSCHE, Friedrich. Ecce homo: como alguém se torna o que é. Tradução por Paulo César de Souza. São Paulo: Companhia das Letras, 2008.
} 
No livro Nietzsche, o bufão dos deuses, ${ }^{3}$ Maria Cristina Franco Ferraz tece um estudo das cartas que coincidem com o período de produção de Ecce homo. Nele, a autora analisa relações familiares, com editores, amigos e inimigos de Nietzsche.

No primeiro capítulo, a autora comenta o tom paródico e equivocado do artigo $\mathrm{O}$ caso Nietzsche, de autoria do wagneriano Richard Pohl, que por sua vez fazia alusão à obra de Nietzsche $O$ caso Wagner. ${ }^{4} \mathrm{O}$ artigo fora publicado em um semanário musical dirigido por E. W. Fritzsch (editor das obras de Nietzsche anteriores à terceira parte de Assim Falou Zaratustra). O comentário diz o seguinte:

\begin{abstract}
Desenvolvendo uma lógica psicologizante já anunciada no subtítulo igualmente paródico de seu artigo ("Um problema psicológico"), Richard Pohl interpreta O caso Wagner como expressão da inveja e da frustração que Nietzsche mostraria enquanto compositor, reduzindo a um mecanismo psicológico bastante primário o complexo fenômeno do afastamento do filósofo em relação a Wagner, ao idealismo e ao romantismo alemães. (FERRAZ, 2017, p. 11)
\end{abstract}

Cabe salientar que o principal motivo da ruptura de Nietzsche com Wagner se deve à adesão desse último à ideologia do Reich e, portanto, ao antissemitismo da época. Nesse sentido, o artigo de Richard Pohl fora oportuno para Nietzsche romper com o editor E. W. Fritzsch, editor não apenas das obras de Nietzsche até o terceiro Zaratustra, como também do semanário de cunho antissemita no qual o artigo de Pohl havia sido publicado. Vê-se, nesse sentido, o esforço de Nietzsche para diferenciar-se da ideologia antissemita e a necessidade de combater associações indevidas que resultariam posteriormente em más interpretações ou distorções grosseiras de suas obras. ${ }^{5}$

\footnotetext{
${ }^{3}$ FERRAZ, Maria Cristina Franco. Nietzsche, o bufão dos deuses. São Paulo: n-1 edições, 2017.

${ }^{4}$ NIETZSCHE, F. O caso Wagner: um problema para músicos; Nietzsche contra Wagner: dossiê de um psicólogo. Tradução por Paulo César de Souza. São Paulo: Companhia das Letras, 2016.

${ }^{5}$ Em carta endereçada ao amigo Franz Overbeck, Nietzsche avalia as consequências positivas do caso PohlFritzsch: "No fundo, este caso é uma sorte de primeira ordem: terei em mãos a posse exclusiva de minha literatura, no momento em que ela se torna vendável. Pois as obras editadas por C. G. Naumann também só pertencem a mim." (NIETZSCHE apud FERRAZ, 2017, p. 16). Naumann fora o último editor de Nietzsche, com o qual estabeleceria um contrato especial de retomada da propriedade intelectual de toda sua obra. Ao contrário dos editores anteriores, Schmeitzner e Fritzsch, ambos comprometidos com os círculos wagnerianos e antissemitas da época, que não favoreciam a circulação das obras de Nietzsche na Alemanha nem no exterior, Naumann "teria todo interesse em distribuir e vender seus livros." (FERRAZ, 2017, p. $15)$.
} 
Outra questão que nos parece importante explorar é a do combate de Nietzsche à falsa modéstia. Como assinala Ferraz (2017, p. 64-65), esse combate acontece em dois níveis. Primeiro, no nível pessoal, em uma carta de agosto de 1883, Nietzsche expressa à sua irmã Elisabeth o combate de forças e a violência que foram necessários, em momentos de debilidade física, para superar a sua natureza modesta. ${ }^{6}$ Em segundo lugar, no nível da cultura, ${ }^{7}$ Nietzsche reconhece a falsa modéstia como um dos elementos da cultura cristã. E é nesse sentido que descreve um combate de forças em meio à doença como elemento positivo no caminho da autossuperação.

Em outras palavras, a superação da modéstia apareceria para Nietzsche como uma forma de transvalorar elementos de uma cultura que considerava decadente.

Nesse sentido, alguns dos títulos dos capítulos de Ecce homo ("Por que sou tão sábio", "Por que sou tão inteligente", "Por que escrevo tão bons livros", "Por que sou um destino") poderiam ser vistos talvez não apenas como indício de superação da modéstia para Nietzsche no plano pessoal, mas também, no plano da cultura, como modo de "transvaloração" de valores morais de sua época ou como modo concreto de diferenciarse da falsa modéstia atribuída a seus contemporâneos.

Ao fazê-lo, Nietzsche pretenderia afirmar assim seu pensamento, em meio a todas as críticas que recebera de leitores equivocados, em suma, de maus leitores.

\section{AUTOELOGIO E NEO-EVANGELISMO LITERÁRIO}

\footnotetext{
6 "Sua carta a Georg Rée me fez pensar muito, e ainda mais sua observação casual de que, apesar de tudo, minha situação na Basileia foi provavelmente a melhor até agora. Eu, no entanto, julgo da seguinte maneira: o único sentido dos terríveis sofrimentos físicos pelos quais passei reside no fato de que, apenas por meio deles, fui arrancado de uma concepção falsa, ou seja, mil vezes baixa demais, da tarefa da minha vida. $E$, já que sou, por natureza, um homem modesto, foram necessários os meios mais violentos para me chamar de volta a mim mesmo." (NIETZSCHE apud FERRAZ, 2017, p. 63).

7 "Deve-se distinguir a cultura (Cultur) da civilização (Civilisation) e lembrar que, em sentido amplo, o conceito nietzschiano de cultura corresponde ao que o uso francês designaria antes pelo termo 'civilisation'. A cultura não visa à formação intelectual nem ao saber, mas engloba o campo constituído pelo conjunto das atividades humanas e de suas produções: moral, religião, arte, filosofia também, estrutura política e social etc. Abarca, portanto, a série de interpretações que caracterizam uma determinada comunidade humana, num estágio preciso de sua história." (WOTLING, 2011, p. 28-29).
} 
Com exceção do prólogo e das seções dedicadas à análise das obras, os títulos dos capítulos de Ecce homo, também pelo estilo autoelogioso ${ }^{8}$ do texto, provocam ainda hoje constrangimento na maioria dos leitores e interpretações, em geral, equivocadas do pensamento de Nietzsche. Tais interpretações são relativamente conhecidas, pois atribuem à ousadia discursiva de Nietzsche os problemas de saúde que enfrentara e que o impossibilitaram posteriormente de seguir sua produção filosófica.

Diferentemente dessas interpretações, propomo-nos pensar o autoelogio em Nietzsche como estratégia retórica e como um gesto filosófico ${ }^{9}$ de grandes proporções, um gesto de "transvaloração dos valores morais", ${ }^{10}$ marcando sua ruptura profunda com as forças linguísticas do cristianismo e da modernidade filosófica.

\section{Na conferência intitulada O quinto "Evangelho" de Nietzsche, em comemoração} ao centenário de sua morte, Peter Sloterdijk define o autor de Zaratustra como uma espécie de "neo-evangelista literário", na medida em que sua aparição no cenário

\footnotetext{
8 "Cabe talvez perguntar se ao jogo de Nietzsche no Ecce homo - por demais caracterizado como enigmático - poderia ser acrescentada uma suspeita interrogativa: seria pertinente lê-lo também como uma construção de eloquência epidíctica ao modo isocrático?" (MUÑOZ, 2019, p. 46). Para a professora Yolanda Gloria Gamboa Muñoz, Ecce homo seria uma obra de estilo epidíctico, ou seja, um elogio a Dionísio, no qual Nietzsche adotara o autoelogio como estratégia discursiva para elogiar seu mestre Dionísio. Nietzsche teria se inspirado em Isócrates, ao adotar em seu texto a retórica epidíctica (Cf. MUÑOZ, 2019, p. 45-47). Para homenagear Dionísio, era preciso que Nietzsche não se depreciasse, era preciso homenagear a si próprio como parte, como um fragmento daquele para quem verdadeiramente endereçaria o elogio. Talvez esteja aí um sentido possível para a assinatura do texto como "Dionísio contra o crucificado". Encontramos também referências à retórica epidíctica em Aristóteles. Tais referências nos auxiliam igualmente na compreensão da estratégia de composição literária do texto de Nietzsche, embora o sentido atribuído por Aristóteles à retórica epidcítica não a qualifique como um gênero literário, como o fizera antes dele Isócrates, mas como um estilo retórico de caráter demonstrativo. Transcrevemos então duas passagens de Aristóteles sobre o tema que nos auxiliam na compreensão do texto de Nietzsche: "para o gênero epidítico o tempo principal é o tempo presente, visto que todos louvam ou censuram eventos atuais, embora também muitas vezes argumentam evocando o passado e conjecturando sobre o futuro." (Aristóteles, Retórica, Livro I, 1358b); "O elogio é um discurso que manifesta a grandeza de uma virtude. É, por conseguinte, necessário mostrar que as ações são virtuosas. Mas o encômio refere-se às obras (e as circunstâncias que as rodeiam concorrem para a prova, como a nobreza e a educação...). E por isso fazemos o encômio de quem realizou algo. As obras são sinais do caráter habitual de uma pessoa." (Aristóteles, Retórica, Livro I, 1368a).

${ }^{9}$ Possivelmente inspirado na leitura de Pierre Klossowski de que a doutrina do "eterno retorno do mesmo", em Nietzsche, indicaria o retorno de determinados gestos filosóficos e não, propriamente, a mera repetição dos acontecimentos na circularidade do tempo, Michel Foucault sugere que a história da filosofia poderia ser vista também como uma espécie de teatro de gestos: "A filosofia não como pensamento, mas como teatro: teatro de mímicas, com cenas múltiplas, fugidias e instantâneas, nas quais os gestos, sem se verem, se fazem signo." (FOUCAULT, 2015, p. 266).

${ }^{10}$ Em Nietzsche, não se pode pensar a "transvaloração" no mesmo sentido da "superação" hegeliana, pois a "superação" em Hegel pressupõe a ideia de um "progresso histórico" que conserva o que haveria de verdadeiro nos momentos anteriores, enquanto a "transvaloração" em Nietzsche pressupõe uma inversão de valores morais historicamente consolidados, tais como a própria "verdade" em termos hegelianos, os valores do cristianismo, da metafísica e da modernidade filosófica.
} 
filosófico configuraria, segundo ele, "uma intervenção nas condições de entendimento da velha Europa" (SLOTERDIJK, 2004, p. 10).

O texto de Sloterdijk expõe a separação histórico-cultural entre o autoelogio individual e o autoelogio coletivo, ou se quisermos, entre o autoelogio direto do falante individual e o autoelogio indireto do falante situado em uma coletividade. Segundo o autor, tal separação pode ser pensada como expressão de uma ruptura linguística fundamental entre as forças modernas e as forças pré-modernas da linguagem. As primeiras culturas monárquicas da Europa ocidental teriam sido responsáveis por tal separação. O discurso autoelogioso estaria então reservado àqueles que, na condição de sacerdotes, rapsodos ou poetas, o fariam de maneira indireta como forma de louvor aos deuses, a Deus, ao senhor, ao chefe, e, por conseguinte, como louvação de forças ou de virtudes comunitárias. Sloterdijk entende que "Esse fato pode ser analisado, de maneira exemplar, na evangelização cristã, no momento em que ela começa a impregnar as condições de entendimento das primeiras sociedades medievais europeias." (2004, p. 20)

Assim, o elogio a Deus, ao senhor, ao chefe ou a um líder político, seria também uma forma de autoelogio indireto. Segundo o autor, o elemento narcísico fora introduzido nas políticas da linguagem quando, ao contrário do que se supõe, o autoelogio direto passou a ser proibido ao falante comum. Sloterdijk descobre que a questão do autoelogio era considerada pelos antigos como algo recorrente. Em outras palavras, todo texto mesmo hoje -, de acordo com os critérios dos antigos, poderia ser considerado um autoelogio.

Sloterdijk (2004, p. 20) cita dois exemplos anteriores a Nietzsche na tradição ocidental: o do sacerdote-poeta Otfried von Weissenburg, que no século IX na região franco-renana "escreveu um Livro dos evangelhos, no qual reconstrói, de modo poético, o Novo Testamento e o traduz para o vernáculo."; e o de Thomas Jefferson, presidente dos Estados Unidos da América (de 1801 a 1809) e principal autor da declaração de independência estadunidense, que escreveu o livro A vida e a moral de Jesus de Nazaré, mais conhecido como "A Bíblia de Jefferson". Ambos são ainda exemplos de aprimoramento dos Evangelhos, que no caso de Thomas Jefferson torna-se mais complexo "uma vez que o autoelogio individual entra em competição com a autoelevação coletiva" (SLOTERDIJK, 2004, p. 26). Em outras palavras, tais exemplos são ainda 
formas literárias de autoelogio indireto, ou seja, textos que elogiam ou que louvam a Deus através de suas respectivas traduções, recortes e transcrições dos evangelhos. Segundo Sloterdijk (2004, p. 41), "Nas comunicações dos modernos, o simples recorte e ocultação de relatos e milagres, comprometedores, não é mais suficiente.”

Em 13 de fevereiro de 1883, Nietzsche escreve a seu editor Ernest Schmeitzner as seguintes palavras:

Mui prezado Sr. Editor... Hoje tenho algo de bom para lhe comunicar: dei um passo decisivo - e penso que ele também lhe será útil. Trata-se de uma pequena obra (não chega a cem páginas), cujo título é o seguinte Assim falou Zaratustra.

Um livro para todos e para ninguém.

Este livro constitui um "poema" ou um quinto "evangelho" ou qualquer coisa para a qual ainda não existe um nome certo: o mais sério e, ao mesmo tempo, o mais hilário de meus testemunhos, acessível a todos. Por isso espero que ele tenha um "efeito imediato (NIETZSCHE apud SLOTERDIJK, 2004, p. 39).

Dois meses depois, em 25 de abril daquele mesmo ano, Nietzsche escrevia a Malvida von Meysenbug: "desafiei todas as religiões e consegui fazer um novo 'livro sagrado’! Agora, falando com toda a seriedade, este livro é tão sério como qualquer outro, mesmo que ele introduza o riso no seio da religião." (NIETZSCHE apud SLOTERDIJK, 2004, p. 40). E no dia 24 de maio, tecera um comentário sobre a primeira parte de Zaratustra em uma carta endereçada a Karl Hillebrand:

Tudo o que pensei, sofri e esperei encontra-se ali e de um modo tal que agora parece que minha vida encontrou uma justificativa. E então novamente me envergonho de mim mesmo: pois, com isso, estendi a mão para as coroas mais excelsas que a humanidade tem para distribuir. (NIETZSCHE apud SLOTERDIJK, 2004, p. 40)

Para Sloterdijk, toda a correspondência de Nietzsche da época do Zaratustra apresenta indícios ou pretensões de um "neoevangelismo literário" em relação a essa obra. E isso se confirma em algumas expressões utilizadas por Nietzsche para definir o projeto literário de seu Zaratustra, tais como: "livro edificante", "livro sagrado", "livro que 
contém o verdadeiro ar das alturas", "testamento" e, ainda, um "quinto evangelho" (SLOTERDIJK, 2004, p. 47-48).

O que está em jogo é uma tentativa por parte de Nietzsche para liberar a linguagem "dos bloqueios que lhe tinham sido impingidos pelo ressentimento metafísico." (SLOTERDIJK, 2004, p. 43). Ao compreender os valores do cristianismo e da metafísica como valores misológicos, isto é, valores de aversão à razão e à lógica, Nietzsche teria então atribuído a seu Zaratustra uma reescrita dos evangelhos como completa inversão dos valores cristãos e metafísicos ocidentais. Entretanto, o "evangelismo" de Nietzsche significa uma oposição radical ao próprio Evangelho, sendo aquele que possui a coragem necessária para uma tal empreitada um "mensageiro alegre" (SLOTERDIJK, 2004, p. 49).

A tese de Sloterdijk nesta conferência pode ser transcrita na seguinte passagem:

\begin{abstract}
gostaria de apresentar a ideia segundo a qual o "narcisismo" nietzscheano constitui fenômeno relevante [...] para a história da linguagem da velha Europa. No fundo, ele significa a revelação da natureza da autoria e do discurso literário. A característica principal do evento linguístico ligado ao nome de "Nietzsche" pode ser descrita da seguinte maneira: neste evento, viola-se a separação cultural entre a boa nova e a autocomemoração - e, com isso, subitamente se desvela o que um autor moderno faz: colocar o texto para si mesmo. Através disso coloca-se em debate, de uma só vez, não somente a economia dos discursos elogiosos e misológicos, mas também o seu fundamento, que reside no tabu que impede o autoelogio. A legitimação desta guinada pode ser obtida através da crítica que Nietzsche tece contra a metafísica e a moral. Pois, nesta crítica, revela-se a ordem de mentiras que serve de base à lógica do elogio indireto - os mecanismos da falsificação que se materializam em frases tais como: "Quem se humilha será exaltado" ou "servir e desaparecer". Se for verdade que a separação entre o "si mesmo" e o louvor nada mais é do que um adiamento provocado através de ressentimento, uma prorrogação contínua do momento em que o falante poderia dizer a si mesmo: permita que eu te elogie, então é permitido interpretar os atentados de Nietzsche contra a discrição como atos de revisão através dos quais ele contradiz, de modo raivoso, a moral tradicional apoiada na humilhação do si mesmo. (SLOTERDIJK, 2004, p. 66-67)
\end{abstract}

Considerando a tese de Sloterdijk e as críticas violentas que Nietzsche sofrera de seus contemporâneos alemães, o que esperar do autor de Zaratustra senão uma reação à altura de seu empreendimento como pensador de seu próprio tempo ou como "médico/psicólogo" de uma longa tradição histórica? A questão do autoelogio em 
Nietzsche não apareceria, desse modo, como uma retomada de valores discursivos da Antiguidade e como estratégia de diferenciação quanto à humilhação individual consolidada pela tradição cristã?

Nesse sentido, pensamos aqui o autoelogio em Nietzsche não apenas como estratégia discursiva para a composição de uma obra literário-filosófica de reversão dos valores morais do cristianismo e da metafísica, mas também como um efeito estilístico por sua retomada de valores linguísticos, éticos e estéticos, da Antiguidade Clássica.

\section{SONHO DE ZARATUSTRA}

Na segunda parte de Assim Falou Zaratustra, no capítulo intitulado O menino com o espelho, depois de despedir-se de seus discípulos, Zaratustra retorna para a solidão de sua caverna na montanha. Passam-se anos, a abundância de sua sabedoria faz crescer também sua dor, e Zaratustra tem um sonho premonitório. ${ }^{11}$ Vejamos a passagem nas palavras de Nietzsche:

Assim transcorreram luas e anos para o solitário; mas sua sabedoria cresceu e causou-lhe dor com sua abundância.

Um dia, porém, ele despertou antes da aurora, refletiu longamente em seu leito e falou enfim a seu coração:

"Com o que me assustei tanto, em meu sonho, que acordei? Não me apareceu um menino com um espelho?

'Ó Zaratustra', disse-me ele, 'olha-te no espelho!'

Ao olhar no espelho, porém, soltei um grito e meu coração se abalou: pois não foi a mim que vi nele, e sim a careta e o riso galhofeiro de um demônio.

Em verdade, compreendo bem demais o sinal e aviso do sonho: minha doutrina está em perigo, o joio quer ser chamado de trigo!

Meus inimigos tornaram-se poderosos e distorceram a imagem de minha doutrina, de modo que os que mais amo se envergonharão das dádivas que lhes fiz.

Perderam-se para mim os amigos; chegou a hora de buscar os meus perdidos!" (NIETZSCHE, 2011, p. 79)

\footnotetext{
${ }^{11}$ Utilizamos a divisão de Artemidoro (2009, p. 22), para leitura e interpretação de sonhos, entre "sonhos teoremáticos" e "sonhos alegóricos". Também o fazemos através de Foucault (2004, p. 163-191).
} 
Zaratustra interpreta, portanto, seu sonho como sinal de que a imagem de sua doutrina corre perigo. O riso zombeteiro de um demônio no espelho é um sinal, não tão evidente, dessa possível interpretação. As dádivas anteriores que fizera a seus discípulos são colocadas em questão. Não por coincidência, é a criança que lhe conduz do sonho ao pesadelo da imagem no espelho. A criança, portanto, como "um novo começo", como a principal personagem de um dos primeiros fragmentos de Zaratustra, ${ }^{12}$ como elemento de criação de novos valores, é quem aponta o enigma a ser decifrado.

Logo a seguir à interpretação do sonho, Zaratustra se põe em pé, como que acometido por uma felicidade iminente, é visto com admiração por sua águia e por sua serpente, e pergunta: “Que me aconteceu, meus animais? [...] Não estou transformado? A bem-aventurança não chegou a mim como um vendaval?" (NIETZSCHE, 2011, p. 79). Por certo, alguns signos dessa transformação, além da criança que lhe indica o enigma do sonho, sejam também os animais que acompanham Zaratustra na cena. A águia, como sinal de altivez, e a serpente, como o animal cuja condição de sobrevivência se relaciona à mudança de sua própria pele, aparecem assim como símbolos dessa transformação. Zaratustra então descerá às Ilhas Bem-Aventuradas para, novamente, junto de seus amigos e inimigos, "falar e presentear e fazer o melhor para os que mais ama!" (NIETZSCHE, 2011, p. 80).

Cabem aqui algumas considerações acerca do método de interpretação dos sonhos em Artemidoro, pensador romano do século II.

Na obra Sobre a interpretação dos sonhos, Artemidoro apresenta, ante a divisão dos "sonhos de acontecimentos" em sonhos "teoremáticos" e "alegóricos", a seguinte definição: "O sonho é um movimento ou uma modelagem polimorfa da alma que significa o bem ou o mal que virá com os acontecimentos futuros.” (2009, p. 23). Artemidoro divide os sonhos em "sonhos de estado" e "sonhos de acontecimentos". Os primeiros seriam, também de acordo com a leitura feita por Foucault (2004, p. 172), relativos a "almas comuns", aparecendo simplesmente como sonhos que revelam estados momentâneos do sujeito, como, por exemplo, sonhar que se está bebendo água diante da

\footnotetext{
12 "Inocência é a criança, e esquecimento; um novo começo, um jogo, uma roda a girar por si mesma, um primeiro movimento, um sagrado dizer-sim.” (NIETZSCHE, 2011, p. 28-29).
} 
sede real do corpo. Enquanto que os segundos, relativos a "almas virtuosas", revelariam certas premonições do espírito em face a acontecimentos futuros. Por sua vez, os "sonhos de acontecimentos" dividem-se em "sonhos teoremáticos", "aqueles cujo desfecho tem semelhança plena com o que mostram", e "sonhos alegóricos", "ao contrário, os sonhos que significam certas coisas por meio de outras.” (ARTEMIDORO, 2009, p. 22)

Cabe, contudo, destacarmos, para nossa leitura, uma diferenciação entre futuro e devir. Futuro, em certa medida, é um tempo inexistente, se considerarmos a dimensão de tempo cronológico, um tempo que efetivamente escapa ao acontecimento, um tempo sempre em fuga em relação ao tempo presente. De outro modo, devir diz respeito a uma dimensão de tempo por vir que se pode já vislumbrar no presente através de sinais, que se relaciona com o presente através de signos que revelam um certo estado de coisas que se apresentam e exigem nossa atenção. ${ }^{13}$ Nesse sentido, a ideia de sonhos premonitórios é pensada aqui segundo essa noção de devir, ou seja, como aquilo que se pode antecipar no presente acerca de acontecimentos possíveis.

Se levarmos em consideração as divisões feitas por Artemidoro, podemos pensar o sonho de Zaratustra como um sonho alegórico. ${ }^{14}$ Isso na medida em que não há nenhum elemento de significação direta nesse sonho que traduza com absoluta clareza a interpretação feita por Zaratustra. O que há é um conjunto de elementos que vão se apresentando ao longo do livro, como o encadeamento de um poema, ao mesmo tempo que o encadeamento de uma obra filosófica, que expressam ou que coincidem com determinados acontecimentos e temores da própria vida do autor.

Nesse sentido, reafirmamos a leitura de Foucault, que vê em Zaratustra um portavoz de Nietzsche. ${ }^{15}$ Vemos, desse modo, fortes indícios na biografia de Nietzsche para

\footnotetext{
13 “O que agora claramente transparece é que nem há tempos futuros nem pretéritos. É impróprio afirmar que os tempos são três: pretérito, presente e futuro. Mas talvez fosse próprio dizer que os tempos são três: presente das coisas passadas, presente das presentes, presente das futuras." (AGOSTINHO, 2015, p. 310). ${ }^{14}$ Foucault expõe algumas dificuldades do texto de Artemidoro para uma identificação entre sonhos de estado e sonhos de acontecimento. Vejamos: “[...] como reconhecer quando se trata de um sonho de estado ou de um sonho de acontecimento? Como determinar se a imagem anuncia diretamente o que ela mostra, ou se é preciso supor que ela é a tradução de alguma outra coisa? Evocando essa dificuldade nas primeiras páginas do livro IV [...], Ardemidoro defende a importância primordial de se interrogar sobre o sujeito que sonha." (FOUCAULT, 2004, p. 170). De nossa parte, acompanhando as observações de Foucault, questionamos: quem sonha esse sonho premonitório de Zaratustra: a imaginação de Nietzsche ou a própria "realidade" do autor?

15 “Zaratustra não é a imagem, mas o signo de Nietzsche." (FOUCAULT, 2004, p. 265).
} 
que pensemos Zaratustra como espécie de porta-voz, como personagem conceitual que abarcaria, além de uma transformação profunda de Nietzsche, ${ }^{16}$ também os anseios e temores do autor em relação à sua obra.

Se considerarmos o período de publicação dos dois primeiros livros de Zaratustra (o ano de 1883), podemos supor relações possíveis entre a passagem analisada do sonho e a série de acontecimentos (presentes e futuros) em relação aos leitores de Nietzsche, aos maus leitores, analisada no começo deste artigo. A vontade de Nietzsche em ser compreendido, aliada à percepção de que seu tempo não lhe daria uma escuta qualificada para seu pensamento, especialmente entre seus conterrâneos, parece-nos confirmar certas intuições iniciais: primeiro, Zaratustra e Nietzsche são a mesma voz; Nietzsche se expressa na voz de Zaratustra; segundo, o sonho premonitório de Zaratustra, aqui analisado, poderia ser visto também como signo de um temor de Nietzsche em face às relações conturbadas de seus contemporâneos com sua obra, a exemplo de todas as distorções a que ela fora submetida; ${ }^{17}$ terceiro, o riso galhofeiro como imagem de um

\footnotetext{
${ }^{16}$ No capítulo de Ecce homo sobre Zaratustra, Nietzsche relata algumas de suas fontes de inspiração: "A concepção fundamental da obra, o pensamento do eterno retorno, a mais elevada forma de afirmação que se pode alcançar, é de agosto de 1881: foi lançado em uma página com o subescrito: 'seis mil pés acima do homem e do tempo'. Naquele dia eu caminhava pelos bosques perto do lago de Silvaplana; detive-me junto a um imponente bloco de pedra em forma de pirâmide, pouco distante de Surlei. Então veio-me esse pensamento. - Retrocedendo alguns meses a partir desse dia, encontro, como signo premonitório, um súbita e profundamente decisiva mudança em meu gosto, sobretudo na música. Talvez se possa ver o Zaratustra inteiro como música; - certamente um renascimento da arte de ouvir era uma precondição para ele." (NIETZSCHE, 2008, p. 79)

${ }^{17}$ No capítulo A transvaloração, da biografia de Nietzsche escrita por R. J. Hollingdale, há uma passagem em que o autor cita um depoimento de Ernst Horneffer, um dos editores da primeira publicação do livro póstumo A vontade de poder: estudos e fragmentos, projeto abandonado por Nietzsche e publicado postumamente em 1901, posteriormente publicada em segunda edição com o subtítulo Ensaio de uma transvaloração de todos os valores. No depoimento, Ernst Horneffer conta que os editores (entre eles, Peter Gast e August Horneffer) trabalhavam sob intensa pressão de Elizabeth Förster, irmã de Nietzsche e detentora dos direitos de sua obra, então diretora do Arquivo Nietzsche. A passagem diz o seguinte: "Nós achávamos que nossa primeira tarefa era ler o Nachlass [herança, legado, em alusão aos fragmentos da obra abandonada por Nietzsche] inteiro para ter uma visão completa do mesmo. Essa leitura preliminar necessária, de suma importância para uma leitura cuidadosa e planejada, ainda não havia sido feita. Os manuscritos, ainda por decifrar e copiar, estavam empilhados; ninguém fazia a menor ideia do que eles continham. Porém, o Arquivo prosseguiu tranquilamente com a publicação. Então começamos a transcrever o Nachlass. Mas isso levava tempo demais para Frau Förster-Nietzsche. A 'monotonia' da nossa forma de trabalhar lhe desagradava profundamente. A ideia dela era terminar o trabalho o mais depressa possível [...] Em resumo, o único objetivo era imprimir os volumes rapidamente. Estávamos diante de uma difícil decisão. Ela estava absolutamente resoluta em seu desejo de concluir uma edição do Nachlass, ainda que precipitada. Sabíamos disso. Se tivéssemos deixado de colaborar, ela teria confiado o trabalho a outra pessoa. Às vezes citava nomes que fariam Nietzsche estremecer. Então decidimos aguentar aquilo o máximo que pudéssemos, para evitar que acontecesse o pior." Na sequência, Hollingdale escreve: "Essas observações se aplicam a fortiori à segunda edição, na qual Elizabeth estava diretamente envolvida. As objeções contra $A$ vontade de poder tal como se apresenta podem ser expostas de forma bastante sucinta: a compilação contém apenas material rejeitado por Nietzsche ou usado em outro lugar sob forma e contexto
} 
demônio no espelho, no pesadelo de Zaratustra, aparece como imagem de sua doutrina distorcida, não propriamente como a imagem de sua "doutrina", pois é, sem dúvida, imprescindível separar todas as distorções contra o pensamento de Nietzsche das imagens propriamente ditas que Nietzsche fazia de sua obra. ${ }^{18}$

Outra questão que poderíamos pensar a partir de nossa leitura do sonho de Zaratustra é a de que o espelho naturalmente inverte toda e qualquer imagem, produzindo como reflexo um certo tipo de distorção. Contudo, o espelho é tido também, em muitas culturas tradicionais, como símbolo de sabedoria e de conhecimento, e, portanto, como símbolo solar.

\begin{abstract}
A Inteligência celeste refletida pelo espelho se identifica simbolicamente com o Sol: é por isso que o espelho é frequentemente um símbolo solar. Mas ele é ao mesmo tempo um símbolo lunar, no sentido em que a Lua, como um espelho, reflete a luz do Sol. (CHEVALIER, 2000, p. 394)
\end{abstract}

"Na tradição Veda", por exemplo, "o espelho é a miragem solar das manifestações; ele simboliza a sucessão de formas, a duração limitada e sempre mutável dos seres." (CHEVALIER, 2000, p. 394). "Além disso, o espelho dá uma imagem invertida da realidade: Aquilo que está no alto é como aquilo que está em baixo" (CHEVALIER, 2000, p. 394).

Talvez possamos pensar a simbologia do espelho, no sonho de Zaratustra, como signo das sucessivas distorções que o pensamento de Nietzsche sofrera entre seus conterrâneos. Mas também como signo de uma "imagem de si" 19 invertida, distorcida por seus leitores críticos alemães, e com a qual Nietzsche teria de lidar, respondendo muitas vezes com ira, através de seus escritos.

\footnotetext{
diferentes (não se faz distinção entre esses dois tipos de material na compilação de Elizabeth); além disso, o modo como os capítulos foram organizados, e a afirmação de que o resultado é a 'obra principal' de Nietzsche não se justificam.” (HOLLINGDALE, 2015, p. 253-254)

${ }^{18}$ A própria palavra "doutrina" poderia ser vista como um contrassenso na filosofia de Nietzsche. Porém, seu uso no Zaratustra talvez se explique pela perspectiva de um Nietzsche "neo-evangelista" de Sloterdijk. E talvez aqui a expressão "doutrina" deva ser colocada entre aspas, na medida em que Nietzsche teria aplicado à voz de seu Zaratustra uma completa inversão da mensagem dos Evangelhos, em outras palavras, uma transvaloração da boa nova cristã.

${ }^{19}$ Tomamos emprestada a expressão do historiador Paul Veyne, a partir da qual elabora uma análise da queda do imperador Nero. (Cf. VEYNE, 1988, p. 09-23).
} 


\section{IMAGEM DE SI}

No texto O indivíduo atingido no coração pelo poder público, Paul Veyne define o sujeito como "um ser ligado à sua própria identidade pela consciência ou pelo conhecimento de si." (1988, p. 09). Veyne parte do princípio de que o sujeito é ao mesmo tempo sujeito no sentido filosófico e no sentido político. Para isso, estabelece um trocadilho com o termo sujet, que em francês pode significar tanto "sujeito", em sentido filosófico e gramatical, como "súdito". A Veyne interessa a imagem que o sujeito faz de si mesmo na condição de obediência ou de desobediência ao poder do Estado. Sujeito, para Veyne (1988, p. 10), é também "um ser que dá valor à imagem que tem de si mesmo. A preocupação com esta imagem pode levá-lo a desobedecer, a revoltar-se, mas também, e é o que sucede mais frequentemente, levá-lo a obedecer ainda mais." Para o autor, a noção de "indivíduo" ou de "sujeito" não se opõe à noção de "sociedade" ou de "Estado". Nas suas palavras, "Pode então dizer-se que esse indivíduo é atingido no coração pelo poder público quando é atingido na sua imagem de si, na relação que tem consigo mesmo quando obedece ao Estado ou à sociedade.” (VEYNE, 1988, p. 10). Veyne distingue a subjetividade dos mecanismos econômicos ou de poder, mas destaca como um dos maiores mecanismos em jogo nos conflitos históricos o ataque à imagem que o indivíduo faz de si mesmo. Pretende demonstrar com isso "que a importância do mecanismo de subjetividade não é menor no domínio político propriamente dito." (VEYNE, 1988, p. 10)

Queremos então saber como certas imagens de Nietzsche foram forjadas por seus críticos, mas também, que imagens Nietzsche constrói para si nos seus livros. É possível identificar uma "imagem de si” em Nietzsche?

Evidente que encontramos nas suas obras não apenas uma, mas múltiplas imagens atribuídas a si. Elencaremos algumas.

Em Ecce homo, no capítulo Porque escrevo tão bons livros, Nietzsche é contundente ao afirmar que seus escritos, embora resultem também de suas experiências 
pessoais, foram no fundo centelhas muito bem pensadas contra a moral vigente do cristianismo e do altruísmo filosófico. Nesta seção do livro, Nietzsche declara a si como um pensador póstumo (NIETZSCHE, 2008, p. 50). Seguramente, aqui, uma primeira imagem. Seguramente, o faz em relação à incompreensão de seus livros por parte da maioria de seus contemporâneos; também, em relação à uma aguçada percepção de que o seu tempo histórico sofria intensas transformações que futuramente confirmariam muitas das suas intuições, mas que o seu tempo de vida, provavelmente pela consciência física da doença que o acometia, se aproximava do fim.

É de conhecimento geral, entre os estudiosos de seu pensamento, que Nietzsche tivera então alguns poucos leitores com os quais pôde efetivamente dialogar. Seus livros não vendiam. E, nesse sentido, a imagem de pensador póstumo relaciona-se à imagem de pensador extemporâneo. Nietzsche intempestivo, para nós aqui, uma segunda imagem. Talvez aí um sentido possível para a afirmação "Uma coisa sou eu, outra são meus escritos." (NIETZSCHE, 2008, p. 50), na medida em que intuía que seus textos pudessem talvez encontrar leitores futuros que estivessem à altura de seu pensamento, que tivessem ouvidos mais finos para escutá-lo. Talvez aí um sentido possível para sua afirmação de que "Em última instância, ninguém pode escutar mais das coisas, livros incluídos, do que aquilo que já sabe. Não se tem ouvido para aquilo a que não se tem acesso a partir da experiência.” (NIETZSCHE, 2008, p. 51). Nietzsche pensador da experiência: talvez daí uma terceira imagem.

É em resposta a uma crítica recebida, em uma resenha geral de seus livros feita por Karl Spitteler, que Nietzsche responderá adiante, no aforismo quarto desse mesmo capítulo, acerca de seu estilo literário. O autor da resenha tratara o seu Zaratustra como respeitável exercício de estilo e, assim, fizera votos de que Nietzsche passasse a cuidar melhor do conteúdo de seus livros. A resposta de Nietzsche não configura meramente uma ironia, mas uma fundamentação própria de seu estilo literário-filosófico, o que nos leva a pensar em sua inspiração recorrente nos poetas antigos. ${ }^{20}$

\footnotetext{
${ }^{20}$ Vejamos uma passagem de $O$ nascimento da tragédia, na qual Nietzsche diferencia a poesia lírica da poesia épica (guardadas as distâncias conceituais que separam o pensador de Ecce homo do pensador daquela obra): "O gênio lírico sente brotar da mística auto-alienação e estado de unidade, um mundo de imagens e de símiles, que tem coloração, causalidade e velocidade completamente diversas do mundo do artista plástico e do épico. Enquanto este último vive no meio dessas imagens, e somente nelas, com jubilosa satisfação e não se cansa de contemplá-las amorosamente em seus menores traços, enquanto até mesmo a
} 
Em resposta à questão do estilo, Nietzsche escrevera o seguinte:

Comunicar um estado, uma tensão interna de pathos por meio de signos, incluído o tempo desses signos - eis o sentido de todo estilo; e considerando que a multiplicidade de estados interiores é em mim extraordinária, há em mim muitas possibilidades de estilo - a mais multifária arte do estilo de que um homem já dispôs. Bom é todo estilo que realmente comunica um estado interior, que não se equivoca nos signos, no tempo dos signos, nos gestos - todas as leis do período são arte dos gestos. Bom estilo em si - pura estupidez, mero "idealismo", algo como o "belo em si", como o "bom em si", como a "coisa em si"... (NIETZSCHE, 2008, p. 54-55).

São muitas as imagens que Nietzsche sugere para si nos seus livros. Nós poderíamos aqui enumerar muitas delas, tal como a imagem do filósofo como "médico", como diagnosticador, como leitor da cultura, como alguém que persegue uma "grande saúde" em contraponto ao adoecimento dos valores metafísicos, ou seja, de um idealismo filosófico tão criticado por Nietzsche. ${ }^{21}$ Entretanto, interessa-nos pensar que talvez

imagem de Aquiles enraivecido é para ele apenas uma imagem cuja raivosa expressão desfruta com aquele seu prazer onírico na aparência - de tal modo que, graças a esse espelho da aparência, fica protegido da unificação e da fusão com suas figuras -, as imagens do poeta lírico, ao contrário, nada são exceto ele mesmo e como que tão-somente objetivações diversas de si próprio. Por essa razão, ele, como centro motor daquele mundo, precisa dizer 'eu': só que essa 'eudade' não é a mesma que a do homem empírico-real, desperto, mas sim a única 'eudade' verdadeiramente existente e eterna, em repouso no fundo das coisas, mediante cujas imagens refletidas o gênio lírico penetra com o olhar até o cerne do ser. Pensemos agora como ele, entre essas reproduções, avista também a si mesmo como não-gênio [...] todo o tumulto de suas paixões e aspirações subjetivas dirigidas para uma determinada coisa que lhe parece real; se agora se nos afigurasse como se o gênio lírico e o não-gênio a ele vinculados fossem por si só aquela palavrinha 'eu', então essa aparência não poderia mais nos transviar, como sem dúvida transviou àqueles que tacharam de lírico o poeta subjetivo. Na verdade, Arquíloco, o homem ardoroso, no amor e no ódio, é apenas uma visão do gênio, que já não é Arquíloco, porém o gênio universal, e exprime simbolicamente seu sofrimento primigênio naquele símile do homem Arquíloco: ao passo que aquele homem Arquíloco que deseja e quer subjetivamente não pode jamais em parte alguma ser poeta." (NIETZSCHE, 2007, p. 42). Seria possível pensarmos, a partir daí, nessa fusão das forças dionisíacas com a palavra poética, uma admiração de Nietzsche também pela força da poesia lírica antiga, e, em consequência, uma justificativa para o seu estilo, mais tarde para a sua concepção ético-estética acerca da existência, como um pathos afirmativo, como um dizer sim à vida através da palavra escrita? Que relações, sem dúvida em caráter especulativo, poderíamos tecer entre essa teorização do "primeiro Nietzsche" e a afirmação de seu último escrito de que $o$ grande poeta se alimenta somente de sua própria realidade? (Cf. NIETZSCHE, 2008, p. 40). Guardadas as diferenças de tratamento em relação ao conceito de imagem, poderíamos a partir daí pensar também a imagem de um "Nietzsche poeta"? Sabemos, porém, que fora em $O$ Nascimento da tragédia que Nietzsche formulou as bases teóricas, posteriormente revistas, de seu "pensamento trágico". (Cf. MACHADO, 1999). "A tarefa de traçar uma imagem de mim, seja do pensador, seja do escritor e poeta [Dichter], parece-me extremamente difícil.” (NIETZSCHE, 2008, p. 121)

21 "Eu espero ainda que um médico filosófico, no sentido excepcional do termo - alguém que persiga o problema da saúde geral de um povo, uma época, de uma raça, da humanidade -, tenha futuramente a coragem de levar ao cúmulo a minha suspeita e de arriscar a seguinte afirmação: em todo o filosofar, até o 
algumas dessas imagens de si em Nietzsche sejam o efeito das relações conturbadas com os poucos leitores e críticos contemporâneos de suas obras; $; 2$ algo que nos leva a crer que seu estilo literário se desenvolvera também a partir daí.

Nesse sentido, tanto as imagens de si como o autoelogio em Nietzsche enquanto estratégia discursiva, como um dizer sim à vida e, portanto, a si mesmo, seriam para nós um resultado direto tanto das distorções que suas obras sofreram, quanto de sua recorrência ao pensamento filosófico e estético dos antigos.

\section{CONSIDERAÇÕES FINAIS}

Pensamos aqui o autoelogio em Nietzsche como resgate de um gesto filosóficoético-estético antigo; algo como uma retomada de valores estéticos para reelaborar modos de existência que busquem superar determinados valores do cristianismo e da modernidade filosófica. Nesse sentido, perguntamos como as distorções do pensamento de Nietzsche the foram oportunas para que pudesse construir certas imagens intempestivas sobre si mesmo; e, também, como a retórica autoelogiosa de Nietzsche serviu para que pudesse afirmar seu pensamento diante de maus leitores, ou até mesmo de falsificadores, lançando assim sua filosofia como um dardo para o futuro.

Por fim, algumas questões que nos parecem pertinentes para investigações históricas sobre a filosofia de Nietzsche e que poderiam contribuir, talvez, para esclarecer determinados mal-entendidos sobre sua obra e seu estilo literário.

Como não pensar nas relações de Nietzsche com seus contemporâneos críticos alemães? Que tipos de vai-e-vem, inversões e distorções de sua filosofia, como também das imagens que Nietzsche fizera de sua obra, teriam ocorrido nessas relações? Não teria Nietzsche, então, colocado na voz de Zaratustra um de seus temores principais em

momento, a questão não foi absolutamente a 'verdade', mas algo diferente, como saúde, futuro, poder, crescimento, vida...” (NIETZSCHE, 2012. p. 12)

22 "Quem acreditou haver compreendido algo de mim, havia me refeito como algo à sua imagem - não raro um oposto de mim, um 'idealista', por exemplo; quem nada havia compreendido de mim, negou que eu tivesse de ser considerado." (NIETZSCHE, 2008, p. 51) 
relação à sua obra: o de que seus contemporâneos, até mesmo amigos ou discípulos, não estariam à altura de seu pensamento, de seu pathos afirmativo em sentido dionisíaco ou mesmo de sua preferência pelo topo das montanhas? E o que teria a ver com isso tudo a solidão de Zaratustra e a solidão de Nietzsche? Quem poderia suportar o retorno de um gesto de pensamento trágico em plena modernidade filosófica? Haveria leitores com ouvidos apurados para isso? Haveria corpo para tanto?

\section{REFERÊNCIAS}

AgOStinHO, Santo. Confissões. Tradução por J. Oliveira e A. Ambrósio de Pina. $6^{\text {a }}$ Edição. Petrópolis, RJ: Vozes, 2015.

ARISTÓTELES. Retórica. Tradução por Manuel Alexandre Júnior, Paulo Farmhouse Alberto e Abel do Nascimento Pena. São Paulo: Folha de S. Paulo, 2015.

ARTEMIDORO. Sobre a interpretação dos sonhos. Tradução por Elena Aguiar. Rio de Janeiro: Zahar, 2009.

CHEVALIER, J. [et al.]. Dicionário de símbolos: mitos, sonhos, costumes, gestos, formas, figuras, cores, números. Tradução por Vera da Costa e Silva [et al.]. 15 Edição. Rio de Janeiro: José Olympio, 2000.

FERRAZ, Maria Cristina Franco. Nietzsche, o bufão dos deuses. São Paulo: n-1 edições, 2017.

FOUCAULT, Michel. "Sonhar com os próprios prazeres. Sobre a 'onirocrítica' de Artemidoro". In: Ética, sexualidade, política. Coleção Ditos \& Escritos V. Organização e seleção de textos Manoel Barros da Mota. Tradução por Elisa Monteiro e Inês Autran Dourado Barbosa. Rio de Janeiro: Forense Universitária, 2004, p. 163-191.

Theatrum Philosophicum. In: Arqueologia das ciências e história dos sistemas de pensamento. Coleção Ditos \& Escritos, v. II. Organização e seleção de textos Manoel Barros da Mota. Tradução por Elisa Monteiro. Rio de Janeiro: Forense Universitária, 2015, p. 240-266.

HOLLINGDALE, R. J. Nietzsche: uma biografia. Tradução por Maria Luisa de Abreu Lima Paz. São Paulo: EDIPRO, 2015.

MACHADO, R. Nietzsche e a verdade. São Paulo: Paz e Terra, 1999.

MUÑOZ, Yolanda Gloria Gamboa. Isócrates e Nietzsche: uma relação perigosa? São Paulo: Paulus, 2019. 
NIETZSCHE, Friedrich. Assim Falou Zaratustra: um livro para todos e para ninguém. Tradução por Paulo César de Souza. São Paulo: Companhia das Letras, 2011.

Ecce homo: como alguém se torna o que é. Tradução por Paulo César de Souza. São Paulo: Companhia das Letras, 2008.

O caso Wagner: um problema para músicos; Nietzsche contra Wagner: dossiê de um psicólogo. Tradução por Paulo César de Souza. São Paulo: Companhia das Letras, 2016.

\section{Letras, 2012.}

A gaia ciência. Tradução por Paulo César de Souza. São Paulo: Companhia das

O nascimento da tragédia: ou helenismo e pessimismo. Tradução por J. Guinsburg. São Paulo: Companhia das Letras, 2007.

SLOTERDIJK, Peter. O quinto "Evangelho" de Nietzsche: é possível melhorar a boa nova? Tradução por Flávio Beno Siebeneichler. Rio de Janeiro: Tempo Brasileiro, 2004.

VEYNE, Paul. "O indivíduo atingido no coração pelo poder público". In: VEYNE, Paul; RICOUER, Paul [et al]. Indivíduo e Poder. Tradução por Isabel Dias Braga. Lisboa: Edições 70, 1988, p. 09-23.

WOTLING, Patrick. Vocabulário de Friedrich Nietzsche. Tradução por Claudia Berliner. São Paulo: WMF Martins Fontes, 2011. 